\title{
What Should We Do as Intellectual Activists? A Comment on the Ethico-political in Knowledge Production
}

\author{
Anna Lundberg
}

"There must be those among whom we can sit down and weep and still be counted as warriors". This quote, by Adrienne Rich from her book Your Native Land, Your Life (1993), has haunted me numerous times while encountering children and their parents in voluntary legal advice groups-families who did not have their asylum claims recognised and therefore were irregularised. I encountered such families while providing counselling or conducting research together with self-organised groups in the Asylum Commission (Elsrud et al. 2021), conducting fieldwork at the Swedish Migration Agency, and working as an independent investigator for the Swedish government proposing legislative changes in the Aliens Act. Fluctuating between anger, hope, and hopelessness, at one time, I cross-stitched Rich's quotation on a pillow, as a gift for a doctoral student I supervised. During our sessions, she had often cried over the violence

\footnotetext{
A. Lundberg $(\bowtie)$

Norrköping, Sweden

e-mail: anna.b.lundberg@liu.se

(C) The Author(s) 2022

M. Sandberg et al. (eds.), Research Methodologies and Ethical Challenges in Digital Migration Studies, Approaches to Social Inequality and Difference, https://doi.org/10.1007/978-3-030-81226-3_11
} 
in the European migration control regime, the unjust refusal to permit the freedom of movement, and over her disappointment at not being able to translate the experiences she had gained during fieldwork into information that enabled her colleagues to understand the gravity of the current political situation.

Rich's "those among whom" is meaningful not only because it grants permission or even validates shedding tears, but also for encouraging collective efforts to develop epistemic communities of belonging (Yuval-Davis 2011), that is, spaces where we can converse about and enable transformative ethico-political research. By using the word ethicopolitical, I mean to invoke attentiveness, responsibility, curiosity, and the awareness that each one of us is capable of collective reflection (Bozalek and Zembylas 2017). It may also imply activism in Patricia Collin's sense of the word: politically engaged scholarship that may take place anywhere anytime, "because ideas and politics are everywhere" (Collins 2013,37 ). Efforts to develop communities of belonging are also symbolised by a means of channelling frustration (and weeping) and persistent confrontation with the question What should we do as intellectual activists?

The classic ethical way to answer What should we do? is to either enquire what anyone who was similarly situated ought to do (universalisation), to ask how, within the scope of given resources, you can do your best for as many people as possible (maximising), or to develop virtues, such as generosity and truthfulness as a guide in decision making.

In this text, I will not advocate any of these ethical queries as the preferred way forward. Nor will I answer the question: What should we $d o$ ? Instead, I want to speak in favour of creating spaces where we may develop as intellectual activists.

I will propose two concepts that are valuable for the creation of such spaces and that I, while reading the present book, see the authors referring to: epistemic injustice and hope. These concepts are also central to the work we do in the transformative collective initiative, the Asylum Commission (Elsrud et al. 2021). In collaboration between researchers, professionals, civil society actors, self-organised groups, and support networks, we examine and analyse the shifts and restrictions that have taken place in recent years' Swedish asylum regulations, as well as the consequences of these changes for people seeking protection, civil society, and welfare workers. The Commission's primary focus is a critical review and exchange of experiences, combined with continuous knowledge-dissemination work that is carried out based on asylum 
seekers' perspectives and lived experiences. Moreover, our ambition is also to think and act in new directions to enable a more solidaristic refugee policy in the future, attempting to provide what Fiorenza Picozza describes as "a contribution to an anticolonial political imagination that can sustain daily struggles against the asylum regime" (Picozza 2021, xxvi).

In the DIGINAUTS initiative, I see, in the same vein this endeavour to avoid harm, to be responsibly engaged, and to speak the truth to the powers that be (see Sandberg and Rossi, Chapter 1). The DIGINAUTS researchers, as seen in the contribution to this book, strive to provide spaces for exchanging experiences of political work with the unpredictability that such work always implies, whether you are in a mostly scientific or primarily activist milieu. I see an awareness that certain questions must be asked over and over again: How can this research benefit society without reproducing the state-sanctioned methods of violence called detention, deportation, rejection? What is "socially beneficial" research and what should it be in a field as politicised as migration in contemporary times of far-reaching and devastating neoliberal transformations? Is it possible to be progressively exploratory in matters concerning the issue of how people seeking sanctuary can be welcomed, without simultaneously confirming the view that some people are not human enough to count as human, which underlies most political proposals in policy discussions about who deserves protection and (formal) inclusion?

In the chapter on emotional introspection, Ninna Nyberg Sørensen points to these queries in her view that "research results have little resonance among political decision makers and the general public, when the ranks of those 'for' and 'against' migration are more sharply drawn, and when humanitarian considerations become subordinated to wishes for control and restraint" (see Chapter 8). No matter how nuanced and committed we may be, and however valuable our research findings are for future policies, migration research that does not reproduce dominant images of migration and its notions of solutions tends to be silenced or emasculated. This is perhaps not so surprising, because, as Bimal Ghosh aptly observed two decades ago, "no other source of tension and anxiety has been more powerful [in the Global North] than the fear, both real and perceived, of huge waves of future emigration from poor and weak states in the years and decades to come" (Ghosh 2000, 10).

Bearing in mind these challenges and doubts concerning the contribution of intellectual activism, in their chapter, Leandros Fischer and Martin 
Bak Jørgensen highlight the expectations they faced within academia and when conducting fieldwork. The "complex responsibilities for highquality and ethical research" are expectations that we need to meet (see Chapter 6). What impact does this have on the answer to a question that my colleagues and I are frequently asked when presenting the Asylum Commission's transformative work, namely: How do you distinguish between your role as a researcher and your role as an activist? How do you separate these roles? What do the expectations that Fischer and Jørgensen describe mean for the scepticism that migrants-unsurprisingly and well-justified as they are-convey when yet another researcher approaches them and makes claims on their time and stories (see Galis' discussion in Chapter 7). One argument put forward is that "there is a stronger imperative to publish less, better-quality research" (Fischer and Jørgensen, Chapter 6). Yet, we know that what counts as high-quality scholarship, what is deemed within its remit, and what it may accomplish in the social world remain very different, though this may be deeply unjust. Many articles in prestigious scientific journals are not openly available. If they are generally accessible, they are read-only by academics. They are rarely translated in a spirit of actively questioning the boundary between activism and academia or in contexts of mutual learning at the intersection of theory and practice. Open access in its current forms is not a solution here, because while it aims to combat commercial publishing channels, it simultaneously stimulates emerging platform monopolies.

Another aspect of engaged scholarship that emerges in this book covers the much needed problematisations of language and framing. In her chapter about big-data-based research, Laura Stielike investigates 17 peer-reviewed publications (Chapter 5). Stielike highlights how three mainstream migration narratives are produced in the papers, which boil down to a framing of migration as something that can be governed more (which is assumed to be necessary) through better data (which implies that research, in turn, is to provide the data). Much data-based migration research of today, Stielike concludes, reproduces an understanding of migration as a phenomenon that changes the size and composition of a population, and that can be influenced to a certain extent through political interventions, an assumed need to integrate migrants into receiving societies, and various forms of humanitarian assistance.

Within my research field, migration law, I also sense such more or less explicit agendas and assumptions, through the use of language, although this is often veiled by the supposedly impartial legal text. More rules 
are often requested in the name of the rule of law and legal certainty. Consider the concepts of economic migrants, third-country nationals, unaccompanied children, and voluntary return. How do we handle such legal-technical terms as they seep into academic literature? In our quest to influence, we easily unconsciously reproduce a policy or even a humanity that we do not think is good at all, or we realise fails on a multitude of important levels.

\section{WHAT TO DO?}

Giacomo Toffano and Kevin Smets (Chapter 4) present an inspiring pathway for new and transdisciplinary narratives in migration research in the Migration Trail. The trail is a visual representation of spatial data, initially assembled to accompany the narrative of two migrants on their journey to Europe. There is David, an ambitious Nigerian entrepreneur with big business plans that were a driving force in leading him through Libya, Italy, and France. And there is Sarah, a 19-year-old Syrian proceeding through the "Balkan Route" continually exchanging messages with her brother. The Migration Trail is an investigation of the interaction of textual, audio, visual, and spatial elements of communication drawing attention to the political, economic, and social dimensions of migration while, at the same time, reaffirming the humanity of people on the move. It represents something that is different from common press accounts and traditional data visualisations or fiction, where migrants often appear as mere victims: passive subjects of political-economic conditions in need of protection. The Migration Trail is indeed a protest against violent migration management and an example of how the repressive development can be criticised by intellectual activists.

All in all, the authors of this book demonstrate and provide alternate understandings of the dominant notions that permeate migration policies, in which people seeking refuge are depicted as "the other". The chapters reach beyond images of undesirable collective masses that must be kept away at all costs, or a vulnerabilised suffering individual who, if let in, will be admitted because it confirms "the us" as human beings (after all). This is done without ending up at the other extreme of the "curated success stories" (Fernandes 2017) where complex lived experiences are restructured into easily absorbable superficial stories. Even though such stories may be mobilised towards beneficial goals, the conditions under which they are told and the response to them involves a risk that the greater circumstances of global inequality will be concealed. 
Epistemic injustice and hope are two concepts that can facilitate the future process of making sense of the question of "What should we do?" and supporting intellectual activists in their solidarity struggles.

\section{EPISTEMIC InJUSTICE}

Epistemic injustice was introduced by the moral philosopher Miranda Fricker in her book of the same name (Epistemic Injustice. Power and the Ethics of Knowing, 2007) to catch the interdependency between knowledge and power. Fricker explains how knowledge production is both political and ethical because it interacts with society's hierarchical arrangements, allowing some perspectives to come forward while others are left out. In the same vein, Gayatri Spivak (1988) has previously used the term "epistemic violence" to describe the disappearing of some knowledge, namely, that of marginalised groups, and how this undermines their ability to speak and be heard. And Pierre Bourdieu has insightfully stated that, "Among the most radical, surest, and best hidden censorships are those which exclude certain individuals from communication (e.g., by not inviting them to a place where people speak with authority, or by putting them in places without speech)" (Bourdieu 1977, 649).

The problem here is not just that others do not try to listen. Even though people in vulnerable positions might be asked to speak, they are rarely considered to be people who know and understand (Boochani et al. 2020). This negligence is seen in much migration research, where migrants are often portrayed as objects without being acknowledged as co-producers of academic knowledge (Grosfoguel et al. 2015).

According to Fricker, epistemic injustice is a form of "double structural discrimination" that is enabled because privileged groups have primary control over society's analytical resources. This discrimination is manifested through the questioning of certain persons' credibility as knowers, called testimonial injustice, and excluding collective interpretive resources that reproduce a form of hermeneutical injustice, i.e., injustice based on the theory and methodology of interpretation, especially of biblical texts. This occurs when the narrative and interpretive resources necessary to describe and understand the experiences of marginalised groups are lacking. It leaves the most vulnerable people unable to understand or make sense of some aspects of their experiences. Alternatively, they understand only too well, but lack the channels to be heard. These injustices, in 
turn, might also lead to a situation where individuals question their right to exist and give up all claims in this respect.

Interpretive (hermeneutical) inequality is very difficult to detect and change, since privileged persons tend to understand those things that it serves them (us) to understand. Consequently, marginalised groups' interpretations of social phenomena remain silenced, even though they might very well be valid and even openly and explicitly requested.

This silencing is indeed a challenge for initiatives such as the Asylum Commission, which gathers actors with various power resources in an attempt to build solidary alliances for transformative knowledge production in the field of asylum rights. In a recent book about the asylum regime, Picozza (2021) reflects on these challenges through ethnographic fieldwork. She argues that the figure of the "refugee" produces its counterpart, the "refugee supporter", "as an embodiment of a specifically European and postcolonial 'good' whiteness, premised on liberal, democratic and humanitarian discourses" (Picozza 2021, xxiii).

Testimonial injustice is easier to spot than hermeneutical injustices. It occurs when a speaker receives less credibility as a result of negative identity prejudice. This injustice is perpetrated against members of groups whose testimonies are questioned and disbelieved because of negative prejudicial stereotypes about those groups. A typical example is when someone seeking protection is not deemed credible due to certain assigned identities, be it "woman", "child", or "HGBTQI+". Another example that has been evident in the Asylum Commission is when people seeking refuge in Sweden turn to politicians to point out shortcomings that have occurred in their asylum process. Such political actions are often based on an experience that the process has not been legally secure and that the concerned people have not been listened to. But for various reasons that may be related to limitations in society's processes for collective understanding and preconceived notions about people seeking asylum, it is very difficult to have one's voice heard. The difficulty is inflated by a strong belief in Sweden as a state governed by the rule of law. It becomes difficult, or even impossible, to put forward arguments that involve a legitimate critique. The image that the Swedish asylum procedure is legally secure seems to have such a deep anchoring in the migration administration's self-understanding that it is difficult to dislodge. This self-deception becomes particularly clear if we consider the "non-political" migration courts, where a ceremonial version of administrative justice is performed, making it extremely challenging to reveal 
injustices. Indeed, this also applies to the broader asylum regime, an order of inequalities (Achiume 2019) that is overshadowed by legalistic arguments and voluntary initiatives that aim to help (Picozza 2021).

What can we, as intellectual activists, do to contest these epistemological injustices? A way forward is offered by the emerging methodological approach referred to as "a scholarship of hope".

\section{Hope}

In a recent anthology developed within the Asylum Commission framework (Elsrud et al. 2021), gender scholar Diana Mulinari describes hope as a concept that captures the vulnerability of life but also a human capacity to act and create other worlds. In this context, the organisation in safe spaces (often behind closed doors), various support groups, legal advice, fundraising, etc., may be understood as a practice of intellectual action and a potential methodological approach that may fruitfully articulate academic knowledge with a hopeful political vision. In this context, slogans such as No frontiers, No nations, Stop deportation; No one is illegal; Not in my name, are a form of hope for solidarity with refugees.

While Fricker inspires intellectual activism, Mulinari and her colleagues $(2018,2020)$ provide helpful reflections about hope as a form of scholarship, and this is an essential aspect of conversations concerning "What should we do?" In particular, their review of the processes at the turn of the millennium, when intersectionality took root in Swedish academia, is truly relevant. Intersectional research approaches had an explicit ambition at the time, to be intellectually activistic and provide politically relevant analyses by conceptualising the effect of economies' interdependence on the lives of human beings in a postcolonial world. Intersectionality also brought an ambition to explore and contest inequalities that are produced and reproduced in (white) academic work. The concept was born out of the black feminist critique of hegemonic "white feminism" and its knowledge production that lacked an understanding of the effects of racism. Moreover, intersectional perspectives were introduced to understand the dynamics of power at a time when the logic of capitalist accumulation was articulated through rationalising and effectivising social relationships.

Inch by inch, Mulinari and de los Reyes explain intersectionality as a perspective and political project has then endured a process of academisation and a dissociation of academic knowledge production from everyday struggles. It became "dislocated from the richness and heterogeneity of 
the Black radical tradition" (De los Reyes and Mulinari 2020, 188). Rather than politicising and re-politicising inequalities, endless discussions took place "about how to put categories together and what categories matter" (De los Reyes and Mulinari 2020, 188). This development went so far that intersectionality was eventually spoken of without naming the role of nation-states in the operations of power and categorisation practices.

One reason that fuelled the depoliticisation was that certain influential scholars such as Kimberlé Crenshaw and Patricia Hill Collins emerged as those who represented the intellectual field. This academisation went hand-in-hand with a gradually increasing inattention to the groundup struggles that provided "the historical, political and epistemological space for the understanding of their theoretical work" (De los Reyes and Mulinari 2020, 188). As a result, knowledge also became depoliticised, allowing for an "unawareness" and a legitimised lack of interest in the conditions of black women's lived experiences as well as in the "heterogeneity of black women's intellectual production" (De los Reyes and Mulinari 2020, 191). It is against this background that Mulinari and her colleagues discuss transdisciplinary visionary research (see Martinsson and Mulinari 2018).

What can we learn from these reflections on translations of intersectionality? In retrospect, some of the epistemological injustices present today derive from the academisation of engaged and critical scholarships such as intersectionality. This circumstance is why scholars of hope should come back to reflect on "What should we do?" and simultaneously engage practically in work that overcomes boundaries between academic work and political engagement. Put differently, to get engaged with: Transdisciplinary struggles to change the uncertain and insecure conditions that permeate the lives and existence of many human beings in contemporary times- "a theory on the flesh" (De los Reyes and Mulinari 2020, 191)—challenging the modern capitalist system, and creating futures outside those provided by hegemonic social relations, are necessary elements of a scholarship of hope.

As I read Mulinari and colleagues, the answer to "What should we do?" is a constant invention and reinvention of formative spaces. I understand this as an on-going process with no clear and ready answers. In these spaces, various positions can be articulated, and common futures can be envisioned. Future-oriented questions may help in the conversations: What would a society beyond racism, patriarchy, heteronormativity, 
and capitalism look like, and how can we reach it? What forms of care or interdependency between human and non-human life would evolve, and how can we make this care flourish?

\section{INTELLECTUAL ACTIVISM}

As intellectual activists, we thus need to commit to people we meet and imagine, and we must struggle for a different world than the one in which we live. In my own community of belonging, this means, among other things, listening carefully to lived experiences of legal (un)certainty and that those who have legal knowledge share this when it is requested or needed. Instead of separating roles, we should constantly let the roles of activists, researchers, and professionals interact. I see separating the roles as a direct impediment to gaining a deeper understanding of legal (un)certainty, the (non)right to asylum and racist border practices. The interaction of roles also implies practical attempts to create coexistence without obscuring tensions, to make room for diversity, and to refuse to simplify. This is no easy task. As the Asylum Commission has experienced, joining forces in one struggle is extremely challenging due to the diversity of those seeking sanctuary in Sweden whose asylum claims have not been recognised, the involved professionals, and the scholars. Yet, this plurality does not mean that we cannot learn from others and-momentarily-also learn as equals.

Acknowledgements I would like to thank my activist intellectual friends, Torun Elsrud, Mehek Muftee, and Emma Söderman, for valuable comments on this text.

\section{BIBLIOGRAPHY}

Achiume, E. Tendayi. 2019. "The Postcolonial Case for Rethinking Borders." Dissent 66 (3): 27-32. Project MUSE.

Boochani, B., et al. 2020. "Transnational Communities for Dismantling Detention: From Manus Island to the UK." Community Psychology in Global Perspective 6 (1): 108-128-128. http://eprints.whiterose.ac.uk/163891/1/ Boochani-etal.pdf.

Bourdieu, Pierre. 1977. "The Economics of Linguistic Exchanges." Social Science Information 16 (6): 645-668. https://doi.org/10.1177/053901847 701600601 . 
Bozalek, Vivienne, and Michalinos Zembylas. 2017. "Towards a Responseable Pedagogy Across Higher Education Institutions in Post-apartheid South Africa: An Ethico-political Analysis." Education as Change 21 (2): 62-85. http://hdl.handle.net/10566/3235.

Collins, Patricia H. 2013. "Truth-Telling and Intellectual Activism." Contexts 12 (1): 36-41.

De los Reyes, Paulina, and Diana Mulinari. 2020. "Hegemonic Feminism Revisited: On the Promises of Intersectionality in Times of the Precarisation of Life." NORA-Nordic Journal of Feminist and Gender Research 28 (3): 183-196.

Elsrud, Torun, Sabine Gruber, and Anna Lundberg. (2021) Asylkommissionen - en antirasistisk forskningspraktik [The Asylum Commission-An Anti-racist Research Practice]. In Anti-rasistiskt socialt arbete $i$ tider av skiftande välfärdsoch migrationsregimer [Anti-racist Social Work in Times of Shifting Welfare and Migration Regimes], edited by J. Johansson, Å. Söderkvist Forkby, and U. Wernesjö. Lund: Studentlitteratur.

Fernandes, Sujatha. 2017. Curated Stories: The Uses and Misuses of Storytelling. Oxford: Oxford University Press.

Ghosh, Bimal. 2000. "Toward a New International Regime for Orderly Movements of People." In Managing Migration: Time for a New International Regime?, edited by Bimal Ghosh, 6-261. Oxford: Oxford University Press.

Grosfoguel, Ramon, Laura Oso, and Anastasia Christou. 2015. "'Racism', Intersectionality and Migration Studies: Framing Some Theoretical Reflections." Identities 22 (6): 635-652.

Martinsson, Lena, and Diana Mulinari, eds. 2018. Dreaming Global Change, Doing Local Feminisms. London: Routledge.

Picozza, Fiorenza. 2021. The Coloniality of Asylum: Mobility, Autonomy and Solidarity in the Wake of Europe's Refugee Crisis. Lanham, MD: Rowman and Littlefield.

Spivak, Gayatri Chakravorty. 1988. "Can the Subaltern Speak?” In Marxism and the Interpretation of Culture, edited by C. Nelson and L. Grossberg, 271-313. Urbana, IL: University of Illinois Press.

Yuval-Davis, Nira. 2011. The Politics of Belonging: Intersectional Contestations. London: Sage. 
Open Access This chapter is licensed under the terms of the Creative Commons Attribution 4.0 International License (http://creativecommons.org/licenses/ by/4.0/), which permits use, sharing, adaptation, distribution and reproduction in any medium or format, as long as you give appropriate credit to the original author(s) and the source, provide a link to the Creative Commons license and indicate if changes were made.

The images or other third party material in this chapter are included in the chapter's Creative Commons license, unless indicated otherwise in a credit line to the material. If material is not included in the chapter's Creative Commons license and your intended use is not permitted by statutory regulation or exceeds the permitted use, you will need to obtain permission directly from the copyright holder.

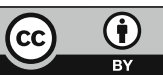

